\title{
Pengaruh Kemoterapi terhadap Sindroma Mata Kering Menggunakan Tes Ferning Okuler
}

\author{
Cristian Rajagukguk *, Sony Agung Santoso **, Soebarkah Basoeki ${ }^{* \star *}$
}

\begin{abstract}
ABSTRAK
Sindroma mata kering (SMK) atau keratoconjunctivitis sicca adalah suatu penyakit multifaktorial pada air mata dan pada permukaan mata yang dapat menyebabkan ketidaknyamanan pada mata, gangguan penglihatan, dan ketidakstabilan lapisan air mata yang berpotensi menimbulkan kerusakan mata. Berdasarkan proses patogenesisnya, SMK disebabkan oleh berkurangnya sekresi air mata dan meningkatnya evaporasi. Kemoterapi merupakan modalitas terapi yang berpotensi untuk menekan sel-sel ganas. Dengan meningkatnya penggunaan regimen kombinasi kemoterapi maka efek samping yang ditimbulkan pada mata pun meningkat. Salah satu efek samping dari kemoterapi ialah SMK. Tes ferning merupakan uji diagnostik yang dilakukan untuk menilai lapisan mukus konjungtiva. Keunggulan pemeriksaan ini ialah tingkat sensitifitas dan spesifisitas yang tinggi yakni sebesar $82,2 \%$ dan $92,5 \%$. Hasil positif tes ini menyatakan pasien mengalami SMK lewat adanya distorsi musin melalui pola ferning. Tujuan penelitian ini adalah mengetahui pengaruh kemoterapi terhadap SMK yang ditandai oleh distorsi musin pada tes ferning. Penelitian ini menggunakan desain observasional analitik dengan membandingkan hasil tes ferning pasien kemoterapi dengan orang sehat. Dari hasil penelitian didapatkan distorsi musin yang signifikan $(p=0,033)$ sehingga dapat disimpulkan bahwa kemoterapi dapat menyebabkan distorsi musin yang ditandai dengan pola ferning tipe III dan IV.
\end{abstract}

Kata kunci: Musin, Kemoterapi, Sindroma mata kering, Tes ferning okuler

\section{Effect of Chemotherapy on Dry Eye Syndrome using Ocular Ferning Test}

\begin{abstract}
Dry eye syndrome (DES) or keratoconjunctivitis sicca is a multifactorial disease of the tears and ocular surface that results in symptoms of eye discomfort, visual disturbances, and tear films instability that potential damage to the ocular surface. According to its pathogenesis, dry eye syndrome is caused by reduced tear secretion and increased tear evaporation. Chemotherapy is a treatment modality that has the potential to suppress the malignant cells. The increasing use of combination chemotherapy regiments may increase the ocular side effects. Dry eye syndrome is one of ocular adverse effects of chemotherapy. Ocular ferning test is a diagnostic test that is carried out to assess the mucus layer of the conjunctiva. The advantages of this examination is its high sensitivity and specificity of $82.2 \%$ and $92.5 \%$. The positive result of this test state that patients suffered from dry eye syndrome will showed mucus distortion on ferning pattern. The purpose of this study was to determine the effect of chemotherapy on dry eye syndrome characterized by distortions of mucus on ferning test. This study used observational analytic design by comparing ocular ferning test results of patients with chemotherapy regiments and healthy persons. The results showed there was a significant distortion of mucin ( $p=0.033$ ) thus it can be concluded that chemotherapy can cause distortion of mucin characterized by ferning patterns type III and IV.
\end{abstract}

Keywords: Chemotherapy, Dry eye syndrome, Mucin, Ocular ferning test.

* Program Studi Pendidikan Dokter, FKUB

** Laboratorium IImu Kesehatan Mata, RSSA-FKUB

*** Laboratorium Patologi Anatomi, RSSA-FKUB 


\section{PENDAHULUAN}

Sindroma mata kering (SMK) atau yang biasa dikenal sebagai keratoconjunctivitis sicca (KCS) adalah suatu penyakit multifaktorial pada air mata dan pada permukaan mata yang dapat menyebabkan ketidaknyamanan pada mata, gangguan penglihatan, dan ketidakstabilan lapisan air mata (LAM) yang berpotensi menimbulkan kerusakan mata. Berdasarkan proses patogenesisnya, SMK dapat disebabkan oleh berkurangnya sekresi air mata dan meningkatnya evaporasi. ${ }^{1,2}$

Lapisan air mata (LAM) memiliki fungsi untuk lubrikasi, mencegah adhesi dengan benda asing, serta mengurangi kemungkinan untuk terjadinya infeksi oleh patogen. Dari luar ke dalam, lapisan ini terdiri dari lapisan lemak, akuos, dan musin. Peran LAM dapat optimal tergantung fungsi dari lacrimal functional unit (LFU). yang terdiri atas kelenjar lakrimal, permukaan okuler termasuk kornea dan konjungtiva, kelopak mata, kelenjar meibom, saraf pada okuler, dan sel-sel goblet. Adanya gangguan pada LFU dapat menggangu fungsi LAM dan menyebabkan SMK. ${ }^{3}$

Prevalensi SMK diperkirakan sekitar 5 $\%$ hingga $35 \%$ pada berbagai rentang umur. Penelitian yang dilakukan di Amerika menunjukkan angka prevalensi SMK berkisar $14 \%$ pada orang dewasa yang berumur 48 hingga 91 tahun. Di Indonesia, prevalensi SMK ialah sekitar 27,5\%, dengan jumlah sampel sebesar 1058 dengan rentang umur $\geq 21$ tahun. Insiden penyakit SMK ialah sebesar 1,22 per 100 orang pada tahun 1991 dan 1,92 per 100 orang pada tahun 1998 di klinik Medicare Amerika. ${ }^{1}$

Ada beberapa gejala yang sering dirasakan oleh pasien yang mengalami SMK, diantaranya: sensasi adanya benda asing, kekeringan mata, perasaan seperti ada pasir di mata, hyperemia, iritasi okuler, keluarnya kotoran mata, fotofobia, pengeluaran air mata yang berlebihan, serta penglihatan kabur. Hal ini tentu dapat mengakibatkan penurunan kualitas hidup apabila gejala-gejala SMK tersebut muncul. 4,5

Tes ferning okuler merupakan uji diagnostik murah dan sederhana yang dapat dilakukan dalam penanganan kecurigaan pada SMK. ${ }^{6}$ Tes ini merupakan uji kualitatif yang dilakukan untuk menilai lapisan mucus dari konjungtiva. Tingkat sensitifitas tes ini ialah sebesar 82,2 \% sedangkan spesifisitasnya ialah $92,5 \%$. Hasil positif tes ini menyatakan pasien mengalami SMK lewat adanya distorsi musin melalui pola ferning. ${ }^{7}$

Kemoterapi merupakan modalitas pengobatan yang digunakan sebagai obat antikanker yang diharapkan dapat mengeradikasi sel kanker tanpa merusak jaringan yang normal. Kebanyakan terapi kemoterapi bekerja hanya pada sel yang aktif bereproduksi. Efek samping dari penggunaan kemoterapi ialah merusak sel sehat yang berproliferasi aktif seperti sel epitel. ${ }^{8}$

Penggunaan berbagai obat-obatan kemoterapi yang luas saat ini memicu terjadinya peningkatan toksisitas yang ditimbulkannya terutama terhadap mata. Salah satu sel-sel epitel yang mengalami kerusakan karena efek samping obat-obatan ini ialah epitel konjungtiva dan epitel kelenjar lakrimal. Sel-sel tersebut akan mengalami apoptosis dan terjadi gangguan sekresi air mata. 9,10

Salah satu efek samping yang ditimbulkan dari beberapa obat kemoterapi yang telah diberikan dari beberapa laporan penelitian sebelumnya ialah SMK. Sampai saat ini penelitian mengenai efek kemoterapi terhadap SMK oleh penurunan produksi lapisan musin pada LAM. Oleh karena itu dibutuhkan penelitian mengenai efek 
kemoterapi terhadap SMK dengan menggunakan tes ferning okuler.

\section{BAHAN DAN METODE}

\section{Desain Penelitian}

Penelitian ini merupakan penelitian observasional analitik. Subjek dibagi menjadi 2 kelompok (kelompok kemoterapi dan kelompok kontrol). Kelompok kemoterapi adalah pasien yang menjalani kemoterapi di Rumah Sakit Saiful Anwar (RSSA) Malang, dengan kriteria mendapat kemoterapi dengan regimen kombinasi (CHOP, ABVD, $\mathrm{dsb})$, sedang menjalani kemoterapi minimal 3 siklus, pasien tidak menderita penyakit autoimun, dan tidak menjalani terapi radiasi selain kemoterapi. Kelompok kontrol adalah pasien normal yang tidak memiliki faktor resiko SMK dan bersedia untuk di anamnesis dan dilakukan pemeriksaan tes ferning okuler.

\section{Lokasi dan Waktu Penelitian}

Penelitian dilakukan di Poli Mata RSSA mulai bulan Juni hingga September 2013.

\section{Sampel Penelitian}

Sampel diambil secara consecutive sampling dalam bulan Juni hingga September 2013 dan didapatkan 22 sampel dengan rincian 11 pasien kemoterapi dan 11 kontrol.

\section{Prosedur Pengambilan Data}

Pasien yang bersedia berpartisipasi dalam penelitian ini akan dilakukan anamnesis dengan panduan kuisioner OSDI (ocular surface disease index) dan dilakukan tes ferning okuler. Tes ferning okuler dilakukan dengan cara mengambil cairan air mata melalui tabung kapiler (glass capillary tube) dari meniskus inferior dan diteteskan di atas kaca objek dan dibiarkan agar mengering lewat proses evaporasi.

\section{Analisis Data}

Analisis data yang digunakan untuk mengetahui adanya hubungan antara kemoterapi dengan hasil tes ferning adalah uji chi-square $\left(\mathrm{x}^{2}\right)$ dan Man-Whitney untuk hubungan antara kemoterapi dengan skor OSDI melalui software SPSS for windows versi 16.0

\section{HASIL}

Penelitian ini dilakukan di Sub Bagian Infeksi dan Imunologi Poli Mata, ruang Mata Rumah Sakit Saiful Anwar Malang Fakultas Kedokteran Universitas Brawijaya Malang. Sampel penelitian dibagi menjadi dua kelompok yakni kelompok kemoterapi (kelompok yang sedang mendapatkan regimen kemoterapi kombinasi) dan kelompok kontrol. Pemeriksaan diagnosis SMK dilakukan dengan cara menganamnesis pasien berdasarkan panduan kuisioner OSDI (ocular surface disease index) dan pemeriksaan penunjang menggunakan tes ferning okuler.

Pada penelitian ini didapatkan 11 sampel pada masing-masing kelompok sehingga jumlah keseluruhan kelompok 22 sampel. Pada kelompok yang sedang mendapatkan regimen kemoterapi didapatkan sebaran usia kurang dari 40 tahun sebanyak $4(36,4 \%)$ sampel dan lebih dari 40 tahun sebanyak 7 (63,6\%) sampel, sedangkan pada kelompok kontrol semua sampel berusia lebih dari 40 tahun. Pada sebaran jenis kelamin didapatkan sampel laki-laki sebanyak $6(54,5 \%)$ orang dan perempuan $5(45,4 \%)$ orang pada kelompok yang sedang mendapatkan regimen kemoterapi, sedangkan pada kelompok kontrol didapatkan sebanyak 5 (45,4\%) orang laki-laki dan 6 (54,5\%) orang perempuan. Rentang siklus kemoterapi yang didapatkan pada kelompok kemoterapi yakni dari 3 siklus hingga 17 siklus serta didapatkan 4 (36 \%) sampel yang menderita 
jenis kanker limfoma non Hodgkin, 6 (55 \%) sampel yang menderita limfoma Hodgkin, dan $1(9 \%)$ sampel yang menderita kanker colli. Data mengenai karakteristik sampel penelitian berdasarkan usia, jenis kelamin dan rentang siklus ditampilkan pada Tabel 1 dan Gambar 1. Rata-rata kelompok kemoterapi sebesar 46,55 dan pada kelompok kontrol sebesar 48,27, dengan nilai $p=0,74(p>0.05)$. Pada data jenis kelamin menunjukkan nilai $p=1,000(p>$ $0,05)$, yang dapat diartikan bahwa kedua kelompok memilki jenis kelamin yang tidak berbeda signifikan, sehingga dapat disimpulkan bahwa data usia dan jenis kelamin pada semua kelompok adalah homogen. Menurut hasil pengujian hubungan jumlah siklus kemoterapi terhadap SMK dengan menggunakan uji independent t-test (dapat dilihat pada Tabel 2) didapatkan nilai $p=0,404(p>0,05)$, sehingga dapat disimpulkan bahwa jumlah siklus kemoterapi tidak memiliki hubungan terhadap terjadinya

Tabel 1. Karakteristik demografi sampel penelitian

\begin{tabular}{|c|c|c|c|c|c|}
\hline & rakteristik & emografi & & & \\
\hline & & & Kemoterapi & Kontrol & \\
\hline Usia & & $>40$ thn & $7(63,6 \%)$ & $11(100 \%)$ & 0,740 \\
\hline & & $<40$ thn & $4(36,4 \%)$ & $0(0 \%)$ & \\
\hline Total & & & $11(100 \%)$ & $11(100 \%)$ & \\
\hline Jenis & Kelamin & Laki-laki & $6(54,5 \%)$ & $5(45,5 \%)$ & 1,000 \\
\hline & & Perempuan & $5(45,5 \%)$ & $6(54,5 \%)$ & \\
\hline Total & & & $11(100 \%)$ & $11(100 \%)$ & \\
\hline
\end{tabular}

Usia

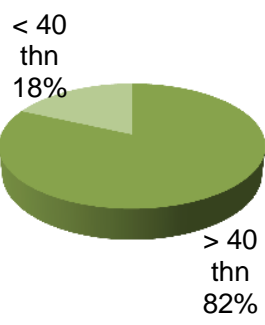

A

\section{Jenis Kanker Pasien yang} Menjalani Kemoterapi

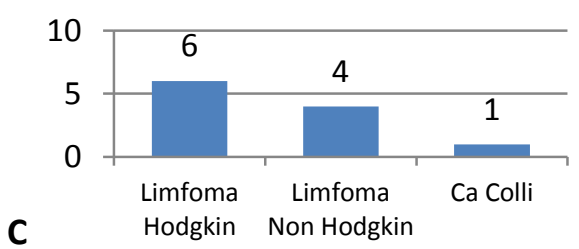

Jenis Kelamin

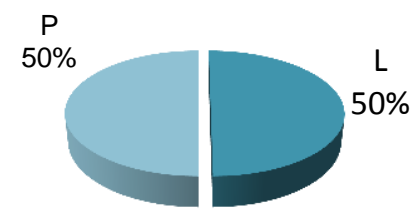

B

Jenis Kemoterapi

$\square$ CHOP ABVD Lain-lain

D

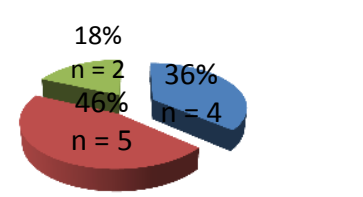

Gambar 1. Karakteristik demografi sampel penelitian berdasarkan usia (A); jenis kelamin (B); jenis kanker yang dialami pasien yang menjalani kemoterapi (C); dan jenis kemoterapi yang dilakukan (D). 
Berdasarkan data karakteristik sampel penelitian pada Tabel 1 dan Gambar 1 dapat diketahui mengenai distribusi sampel pada setiap kelompok. Menurut hasil pengujian umur sampel dengan menggunakan uji independent $t$-test, didapatkan nilai $p=0,740$ $(p>0,05)$, sehingga dapat disimpulkan bahwa umur sampel pada kedua kelompok tidak terdapat perbedaan yang signifikan. Menurut hasil pengujian rata-rata umur sampel terhadap kelompok kemoterapi maupun kelompok kontrol didapatkan adanya SMK. Berdasarkan Tabel 3 didapatkan nilai signifikansi chi-square untuk mengetahui adanya pengaruh pemberian regimen kemoterapi terhadap terjadinya SMK yang diukur berdasarkan hasil pemeriksaan ferning okuler sebesar $p=$ $0,033 \quad(p<0,05)$, sehingga dapat disimpulkan bahwa kemoterapi mempunyai pengaruh yang signifikan terhadap lapisan mukus konjungtiva yang diamati melalui pemeriksaan ferning okuler.

Tabel 2. Hasil uji independent t-test jumlah siklus kemoterapi terhadap terjadinya SMK yang diamati melalui tes ferning okuler

\begin{tabular}{lccc}
\hline & Kemoterapi & Rata-rata & $p$-value \\
\hline Siklus Kemoterapi & Positif & 6.33 & 0.404 \\
& Negatif & 8.60 & \\
\hline
\end{tabular}

Tabel 3. Tabulasi silang kelompok penelitian terhadap tes ferning okuler

\begin{tabular}{ccccc}
\hline Kelompok & \multicolumn{2}{c}{ Tes Ferning } & Total & $p$-value \\
\cline { 2 - 3 } & Positif (SMK) & $\begin{array}{c}\text { Negatif } \\
\text { (Tidak SMK) }\end{array}$ & \\
\hline Kemoterapi & $5(83,3 \%)$ & $6(37,5 \%)$ & $11(50 \%)$ & $0,033^{*}$ \\
Kontrol & $1(16,7 \%)$ & $10(62,5 \%)$ & $11(50 \%)$ & \\
Total & $6(100 \%)$ & $16(100 \%)$ & $22(100 \%)$ & \\
\hline
\end{tabular}

${ }^{*}$ chi-square pengaruh kemoterapi terhadap hasil pemeriksaan tes ferning okuler.

\section{PEMBAHASAN}

Sampel pada penelitian ini merupakan pasien yang sedang menjalani pengobatan kemoterapi kombinasi dengan minimal 3 siklus mengacu pada penelitian terdahulu yang menyatakan bahwa efek samping pada orang yang sedang menjalani kemoterapi mulai terjadi pada bulan kedua dan ketiga pengobatan sehingga ditetapkan cut off value minimal pada pasien yang sedang memasuki siklus ketiga regimen kemoterapi. ${ }^{11}$ Berdasarkan hasil analisis data sebelumnya dapat dilihat bahwa terdapat keseimbangan jumlah sampel berjenis kelamin laki-laki dan perempuan yakni 11 orang laki-laki dan 11 orang perempuan. Dengan menggunakan uji chisquare didapatkan tidak adanya perbedaan yang signifikan jenis kelamin yang dapat diartikan bahwa tidak ada pengaruh jenis kelamin dalam penelitian ini.

Selama penelitian berlangsung, didapatkan kesulitan dalam memperoleh sampel terutama pada kelompok kemoterapi yang berumur lebih dari 40 tahun. Walaupun demikian, berdasarkan hasil uji independent test terhadap umur sampel didapatkan tidak 
ada perbedaan yang signifikan pada umur pasien, baik pada kelompok sampel maupun kontrol $(p=0.740)$, sehingga pengaruh umur dapat disingkirkan dalam penelitian ini.

Tes ferning okuler merupakan pemeriksaan yang dilakukan untuk menilai lapisan mukus konjungtiva. Pengambilan sampel dilakukan dengan cara mengambil cairan air mata melalui tabung kapiler (glass capillary tube) dari meniskus inferior dan diteteskan di atas kaca objek dan dibiarkan agar mengering lewat proses evaporasi. Untuk menentukan hasil diagnosis pemeriksaan tes ini, maka gambaran ferning yang diamati lewat mikroskop diklasifikasikan menjadi 4 menurut klasifikasi Rolando (1984) dengan pola ferning tipe 1 dan 2 merupakan gambaran yang normal serta pola ferning 3 dan 4 sebagai gambaran pasien yang mengalami SMK.

Pada Tabel 3 ditunjukkan hasil uji chisquare pada pengaruh kemoterapi terhadap hasil pemeriksaan ferning okuler. Dari hasil uji tersebut didapatkan nilai signifikansi pengaruh pemberian regimen kemoterapi terhadap hasil pemeriksaan ferning okuler sebesar $p=0,033(p<0,05)$, sehingga dapat disimpulkan bahwa kemoterapi mempunyai pengaruh yang signifikan terhadap lapisan mukus konjungtiva yang diamati melalui hasil pemeriksaan ferning okuler.

Selain menghambat partumbuhan sel kanker, kemoterapi juga merusak sel sehat yang berproliferasi aktif seperti sel epitel. ${ }^{8}$ Sel epitel konjungtiva mengalami apoptosis pada SMK, dan sel kelenjar yang merupakan derivat dari sel epitel secara tidak langsung terganggu oleh proses ini. Mekanisme penurunan produksi musin yang ditandai lewat gambaran ferning kemungkinan dikarenakan adanya apoptosis pada sel-sel epitel konjungtiva yang merupakan penghasil produk musin pada lapisan air mata. ${ }^{10,11}$
Apoptosis yang terjadi pada sel-sel epitel konjungtiva dapat menyebabkan gangguan produksi musin. Apoptosis dapat terjadi karena aktivasi beberapa jalur apoptosis seperti Fas, FasL, Bax, kaspase, perforin, dan granzim. Apoptosis juga dihasilkan oleh ketidakseimbangan faktorfaktor pro-apoptosis (Fas, Bax) dan antiapoptosis (Bcl-2, Bcl-X). Inflamasi sel epitel kelenjar lakrimal mengekspresikan sitokin proinflamasi (IL-1, TNF-a), protoonkogen (cmyc), autoantigen (Ro, La, a-fodrin), dan molekul kostimulator (B7) yang juga berperan pada apoptosis kelenjar lakrimal. ${ }^{12,13}$

Pada Gambar 1D dapat dilihat jenis regimen kemoterapi dan kombinasi yang digunakan dalam pengobatan sebagai antikanker diantaranya $\mathrm{CHOP}$ (Cyclophospha-mide, Doxorubicine, Vincristin, Prednisone) dan ABVD (Doxorubicin, Bleomycin, Vinblastine dan Decarbazine). Ada beberapa obat kemoterapi yang dapat menyebabkan efek samping terhadap mata termasuk salah satu diantaranya menyebabkan SMK. Regimen kemoterapi yang dapat menyebabkan terjadinya SMK antara lain cyclophosphamide, pentostatin, nilotinib, imatinib, dan busulphan. ${ }^{10}$ Padahal dari penelitian ini dapat dilihat pada kelompok kemoterapi terdapat lebih banyak pasien yang menderita penyakit limfoma Hodgkin (sebanyak 6 orang) dengan regimen kemoterapi yang berbeda dengan regimen kemoterapi yang sering menyebabkan SMK. Selain itu terdapat pula pasien yang menderita limfoma non Hodgkin sebanyak 4 orang dengan regimen kombinasi kemoterapinya mengandung salah satu regimen kemoterapi yang dapat menyebabkan SMK yakni cyclophosphamide.

Menurut DEWS, kuesioner OSDI merupakan kuesioner yang valid dan terpercaya untuk mengevaluasi frekuensi dan tingkat keparahan SMK secara 
individual dan dampak yang ditimbulkannya terhadap kualitas hidup pasien. Adapun hasilnya dapat dinilai lewat skala skor 0 hingga 100 , dengan nilai normal $=0-12$, ringan $=13-22$, sedang $=23-32$, dan berat $=$ 33-100. ${ }^{1}$

Pada penelitian ini didapatkan rata-rata skor OSDI untuk kelompok yang mendapatkan regimen kemoterapi sebesar 9,18 yang berarti masuk dalam kategori normal, sedangkan rata-rata skor OSDI untuk kelompok kontrol ialah sebesar 13,82 yang berarti masuk dalam kategori SMK derajat ringan. Akan tetapi dari hasil uji Mann Whitney $\mathrm{U}$ didapatkan hasil yang tidak signifikan yakni $0,093(p>0,05)$, sehingga dapat disimpulkan bahwa kemoterapi memiliki pengaruh yang tidak signifikan pada skor OSDI. Pengaruh jumlah siklus kemoterapi dianalisis dengan independent $t$ test dan menunjukkan tidak terdapat hubungan antara jumlah siklus kemoterapi terhadap hasil tes ferning.

Dari ulasan di atas dapat disimpulkan bahwa kemoterapi kombinasi dapat menaikkan kejadian terjadinya SMK. Penemuan skor OSDI berkontradiksi dengan penemuan pada produksi musin, namun hal ini dapat diperbolehkan mengingat pada kebanyakan kasus sering terdapat korelasi yang tidak konsisten antara gejala dan tanda klinis (lewat pemeriksaan diagnostik) yang ada. ${ }^{14}$

Dari penelitian yang dilakukan, peneliti menyadari bahwa masih terdapat banyak keterbatasan sehingga beberapa faktor yang dapat mempengaruhi penelitian tidak dapat dimasukkan. Faktor yang berpengaruh antara lain jumlah sampel yang sedikit, waktu penelitian yang singkat, subjektivitas dalam penilaian gambaran ferning, dan beberapa hal lain yang mungkin tidak terdeteksi oleh peneliti sehingga kemungkinan terjadinya bias dalam penelitian ini tidak dapat disingkirkan dan merupakan kelemahan dari penelitian ini.

\section{KESIMPULAN}

Dari hasil penelitian ini dapat disimpulkan bahwa kemoterapi memiliki pengaruh terhadap lapisan mukus konjungtiva dengan adanya penurunan produksi musin yang ditandai dengan gambaran pola ferning tipe III dan IV.

\section{DAFTAR PUSTAKA}

1. Dry Eye Workshop. The Definition and Classification of Dry Eye Disease: Report of the Definition and Classification Subcommitee of the International Dry Eye Workshop. Ocul Surf. 2007; 5(2):75-92.

2. Lemp MA. Report of the National Eye Institute/Industry Workshop on Clinical Trials in Dry Eye. CLAO J. 1995; 21:221-32.

3. Rolando M dan M Zierhud. The Ocular Surface and Tear Film and Their Dysfunction in Dry Eye Disease. Surv Ophthalmol. 2001; 45:202-210.

4. Cintia S, DE Pavia, Pflugfelder SC. Diagnostic Approaches to Lacrimal Keratoconjunctivitis. In: Pflungfelder SC (Editor). Dry Eye and Ocular Surface Disorder. New York: Marcel Dekker. 2004; p 270.

5. Gayton JL. Etiology, Prevalence, and Treatment of Dry Eye Disease. Clinical Ophtalmolog. 2009; 3:405-412.

6. Riordan-Eva P, P Whitcher. Vaughan dan Asbury's General Ophthalmology. 17th Edition. McGraw-Hill. 2007.

7. Albach KA, Lauer M, Stolze $\mathrm{HH}$. Diagnosis of Kerato-Conjunctivitis Sicca in Rheumatoid Arthritis. The Value of Various Tests. Ophthalmologe. 1994; 91(2):229-34.

8. Cancer Health Center. Questions and Answers About Chemotherapy. (Online). 2012.http://www.webmd.com/cancer/qu estions-answers- 
chemotherapy?page $=1 . \quad$ Diakses 2 Desember 2012.

9. Al-Tweigeri T, Jean-Marc Nabholtz, John Robert Mackey. Ocular Toxicity and Cancer Chemotherapy. 1996.

10. Singh $P$ and Singh A. Ocular Adverse Effects of Anti-Cancer Chemotherapy and Targeted Therapy. Journal of Cancer Therapeutics \& Research. 2012.

11. Reinoso R, Calonge M, Castellanos $\mathrm{E}$, Martiono M, Fernandez I, Stern ME, Corell A. Differential Cell Proliferation, Apoptosis, and Immune Response in Healthy and Evaporative-Type Dry Eye Conjunctival Epithelia. Invest Ophthalmol Vis Sci. 2011; 52(7):48194828.
12. Tapinos NI, Polihronis M, Tzioufas AG, Skopouli FN. Immunopathology of Sjogren's Syndrome. Ann Med Interne. 1998;149:17-24.

13. Mariete X. Pathophysiology of Sjogren's Syndrome. Ann Med Interne. 2003; 154:157-168.

14. Johnston L. Keratoconjunctivitis Sicca (Dry Eye). S Afr Pharm J. 2012; 79(1):33-37. 